\title{
Vessel Monitoring System Using GSM Communications Network
}

\author{
Eko Prayetno $^{1}$, Deny Nusyirwan ${ }^{1}$, Sapta Nugraha ${ }^{1}$, Ade Faturrahman ${ }^{1}$, Dedi Pandu Winata ${ }^{1}$ \\ ${ }^{1}$ Raja Ali Haji Maritime University, Engineering Faculty, 29124 Tanjungpinang, Indonesia
}

\begin{abstract}
The purpose of this study is to monitor the data sent from the ship to the server. This system relies on the internet network to transmit data such as the coordinates of ship position, the direction vessel, the distance of obstacles in a front vessel, the speed vessel, and the length of ship trajectory to the server using the GSM Shield SIM900 module. This study will use four providers such as Telkomsel, XL Axiata, Indosat, and Tri. The benefit of this ship monitoring system research is that it can monitor supervision on ships and access via mobile phones. The result of this study is the system can respond well and send data on the coordinates, the direction, the distance of the obstacle in a front vessel, the speed, and the length of the vessel trajectory. Then the best signal strength is using a Simpati card provider with a signal strength of -65 $\mathrm{dBm}$
\end{abstract}

\section{Introduction}

Monitoring is a process for monitoring an ongoing activity to ensure activities continue as planned. The monitoring system is a service that makes the process of collection and the analysis of data to ongoing activities that have not deviated from the planned [1]. The monitoring system also can be implemented on the automatic vessel. Importance of monitoring systems for ships autopilot can see the ship's data from a distance and can monitoring wherever we are to facilitate the vessel's supervision.

The purpose of the ship monitoring system is to monitor the data sent from the ship to the server. The data is a route on the Internet network, and the transmitted data is GPS data, compass, and ultrasound. This monitoring system still relies heavily on the Internet network to send data to the server. The Arduino microcontroller circuit controls the vessel monitoring system by utilizing GPRS using the SIM900 Internet network to transmit data to the server. The data can be viewed via a mobile phone. The study of vessel position tracking system uses GPS applied on android mobile and communicates with a computer to monitor the ship position with the web interface. This application can search for the point coordinates, transmit them to the server, and display the ship position in a map based on the coordinates from an application client. The drawback is that it can only monitor the presence of the ship position and can only access through the android application. Furthermore, this system cannot know the direction of the ship. This system cannot detect obstacles in front of the vessel [2].

The system uses a GSM module to transmit the vehicle position, speed, and when the vehicle remotely by sending an SMS to the GSM module is part of a server. The microcontroller will process the data from the GPS. Point coordinates are displayed on the monitor screen electronic map. This system has the disadvantage of transmitting only vehicle function information, automobile pace, and time vehicles via SMS [3]. Within the observe titled GPS packages based on GSM modem on bus monitoring, the layout of this bus monitoring gadget automatically and real-time the use of GPS era. Furthermore, this device has the disadvantage that the location of the bus inside the shape of maps can only be visible the usage of a pc server on the bus fores tall, and the area is still in the condition of LED lighting fixtures [4].

There are many more studies on monitoring systems using the GSM Network, such as the Smart Garbage Monitoring System [4], Flood Monitoring System [5], health monitoring system for patients [6], Gas Leak Monitoring System [7,8]. The main advantage of Global System for Mobile Communications (GSM) is international roaming capabilities. With these capabilities, GSM services can reach remote areas [9]. General Packet Radio Service (GPRS) is a packetswitching technology that enables data transmission through the Global System for Mobile Communications (GSM) cellular network. GPRS can transmit data in the form of multimedia, e-mail, the wireless application protocol (WAP), and the World Wide Web [10-12].

Based on the study of several previous studies related to the development of a monitoring system that still showed unsatisfactory results. This study's focus is to develop an autopilot vessel monitoring system based on the web. Monitoring displayed on the web such as the vessel's position in the form of maps, vessel obstruction distance, a direction of the ship, the ship's speed, and knowing the distance traversed the vessel. The system can be accessed using a mobile phone available. 


\section{Research Method}

The research methodology carried out in the development of a monitoring system is prototyping. A phase of the study began from several studies related literature similar studies and technologies used in the design of the research system. Collecting data of this study is the manual way to view data such as the coordinates, obstacle distance, direction of the ship, the ship's speed, and space to the ship's destination aboard the ship using the monitor serial Arduino. The design of the monitoring system for the automatic vessel, arranged by integrating five modules like Figure 1.

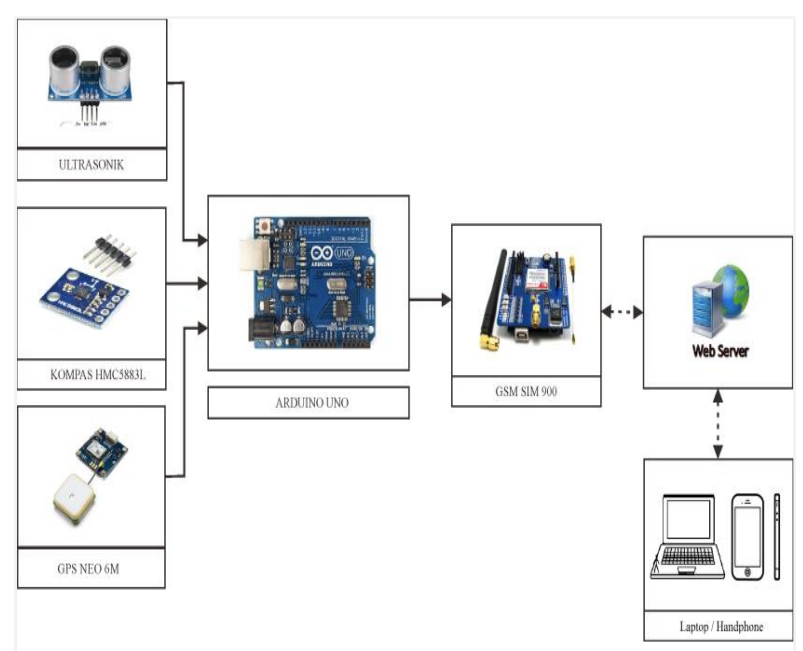

Figure 1. System Design Tool

Figure 1 is a system design consisting of main parts: the input consists of a GPS module to determine the ship's position, speed, and distance to the destination aboard a boat. Global Positioning System (GPS) can continuously provide consistent positioning, navigation, and timing services to users worldwide in any weather, day and night, anywhere on or near the earth. Furthermore, it can view four or more GPS without hindrance Satellite. GPS consists of three parts: space, control, and user [13]. First, the module compass determines the direction of movement of the ship, and the ultrasonic module determines the distance of obstacles in front of the vessel. Then use Arduino to process; the output terminal is GSM SIM900. Next, the system uses the GSM modem to send all the parameters to the control center through the GSM network, which is received and processed by the GSM modem and displayed on the monitor [14].

The device's workings begin to turn on all the research as a GPS, compass modules, and ultrasonic sensors module. The device's workings began to turn on the investigation as a GPS, compass modules, and ultrasonic sensors module. The device SIM 900 was used for this study, which serves as a tool to transmit data. The results of data from SIM900, sending to the server via the GPRS network. In this module, the device connected to GND pin, VCC, 7, and 8 on the port system works Arduino. After all, the data will be processed using a microcontroller displayed on the web. The data shows that latitude, longitude, distance obstacle, the direction of motion of the ship, speed, and distance to the destination aboard a boat.

\section{Results and Discussion}

The power supply circuit used to provide microcontroller supply voltage must be stable and have sufficient current to the microcontroller to supply the voltage drop that does not occur when the microcontroller operates. The device's power supply decreased from the six batteries by using a series of parallel series. One battery has a voltage of 3.7 volts, and two batteries in series to a voltage of 7.4 volts - the battery's output voltage is to supply this to Arduino and SIM900. The test results indicate the battery using a multimeter voltage of 7.74 VDC, which is displayed on the multimeter display is 7.4 VDC. There is a difference of 0.3 volts due to the level of accuracy in the multimeter is lacking.

Testing Arduino conducted to determine whether any digital port Arduino functioning properly or not, researchers conducted tests on a digital port pin 0 , pin 1 , pin 2 , pin 3 , pin 4 , pin 5 , pin 6 , pin 7 , pin 8 , pin 9 , pin 10 , pin 11 , pin 12, and pin 13. Pin Arduino installed an LED lamp alternately to ensure all ports were in good shape. The output voltage is measured using a multimeter to ensure the output voltage according to the datasheet. Arduino test results performed on the digital port 0 to 13 show that the program is high. Therefore, the LED light will light attached, and pull out the digital output voltage of 5 volts, nor vice versa; when the program is to work in a low state, the LED is not lit and did not issue a digital pin the appropriate voltage. Therefore, it can conclude that the Arduino testing showed that all Arduino digital port is functioning correctly.

This study used SIM 900 as the device from Arduino to the internet. The testing SIM900 did know that the SIM900 can work well or not as the interface device. Testing did by inserting a sim card in the ports are located on the bottom of the module. After a sim card is placed, connect SIM900 with Arduino. Press the power button on the SIM900 button, push and hold the button for 2 seconds, and note the LED indicator. SIM900 will be active and usually work when the hand LED stops 3 to 12 times the flicker. When it exceeds 12 times, the flicker then turns off and then turns it back SIM900 for the maximum hint in searching for signals is 12 times hint. Blink on the LED indicates that the SIM900 looked for alerts and stopped when a motion was detected.

The better providers, the faster the search process signals, nor vice versa getting worse providers who used the longer the search process also signals that do SIM900. This study uses a Telkomsel provider, so it only takes 3 to 5 times the blink to get the signal. The following process in the testing SIM900 is using Arduino software IDE. Testing used AT commands Command to see the monitor as a serial success or failure of the data transmission process. Nor vice versa getting worse providers who used the longer the search process also signals that do SIM900. 
In this study, using a 4 provider Telkomsel, XL Axiata, Indosat, and Tri. Here, using four providers is done to determine where there are not many errors to send data to the server. Data retrieval was carried out three times for each provider on the same day but at different hours. Tests doing in the morning, afternoon, and evening. When using a sympathy card, ship data can be sent entirely (Table 1). It indicates a stable signal connection.

\begin{tabular}{|c|c|c|c|c|c|c|}
\hline \multirow[t]{2}{*}{ No. } & \multirow{2}{*}{$\begin{array}{l}\text { How to } \\
\text { Capture }\end{array}$} & \multicolumn{5}{|c|}{ Data } \\
\hline & & $\begin{array}{c}\text { Coordinates } \\
\text { (lat, long) }\end{array}$ & $\begin{array}{c}\text { Distance } \\
\text { Hitch (cm) }\end{array}$ & $\begin{array}{c}\text { Compass } \\
\left({ }^{\circ}\right)\end{array}$ & $\begin{array}{l}\begin{array}{l}\text { Speed } \\
\text { (knots) }\end{array} \\
\text { (n)o }\end{array}$ & $\begin{array}{c}\text { Distance } \\
\text { Boats - } \\
\text { Objective (m) }\end{array}$ \\
\hline 1. & \multirow{6}{*}{$\begin{array}{c}\text { Serial } \\
\text { Monitor }\end{array}$} & $\begin{array}{c}0.912375 \\
104.45508\end{array}$ & 332 & 130 & 0:01 & 10.84 \\
\hline 2. & & $\begin{array}{c}0.912364 \\
104.45510\end{array}$ & 331 & 132 & $0: 03$ & $8: 12$ \\
\hline 3. & & $\begin{array}{c}0.912357 \\
104.45512\end{array}$ & 333 & 134 & $0: 04$ & $6: 41$ \\
\hline 4. & & $\begin{array}{c}0.912347 \\
104.45513\end{array}$ & 330 & 135 & $0: 04$ & $4: 48$ \\
\hline 5. & & $\begin{array}{c}0.912332 \\
104.45514\end{array}$ & 280 & 136 & $0: 03$ & 2.65 \\
\hline 6. & & $\begin{array}{c}0.912317 \\
104.45520 \\
\end{array}$ & 40 & 133 & $0: 01$ & $0: 46$ \\
\hline 7. & \multirow{6}{*}{ Database } & $\begin{array}{c}0.912375 \\
104.45508\end{array}$ & 332 & 130 & $0: 01$ & 10.84 \\
\hline 8. & & $\begin{array}{c}0.912364 \\
104.45510\end{array}$ & 331 & 132 & $0: 03$ & $8: 12$ \\
\hline 9. & & $\begin{array}{c}0.912357 \\
104.45512\end{array}$ & 333 & 134 & $0: 04$ & 6:41 \\
\hline 10. & & $\begin{array}{c}0.912347 \\
104.45513\end{array}$ & 330 & 135 & $0: 04$ & $4: 48$ \\
\hline 11. & & $\begin{array}{c}0.912332 \\
104.45514\end{array}$ & 280 & 136 & $0: 03$ & 2.65 \\
\hline 12. & & $\begin{array}{c}0.912317 \\
104.45520\end{array}$ & 40 & 133 & 0:01 & $0: 46$ \\
\hline
\end{tabular}

Table 1. Testing Using Simpati Cards

When using the axis card, two data failed to send, one in the afternoon and one in the afternoon (Table 2) data undeliverable due to unstable signal connections during the day and evening. When using the IM3 card, seven data failed to send two data in the morning, two in the afternoon, and three in the afternoon (Table 3) Data undeliverable due to unstable signal connections in the morning, afternoon, and evening. When using the tri card, three data failed to send: one in the morning, one in the afternoon, and one in the afternoon (Table 4). Information is undeliverable due to unstable signal connections in the morning, afternoon, and evening.

\begin{tabular}{|c|c|c|c|c|c|c|}
\hline \multirow[b]{2}{*}{ No. } & \multirow[b]{2}{*}{$\begin{array}{l}\text { How to } \\
\text { Capture }\end{array}$} & \multicolumn{5}{|c|}{ Data } \\
\hline & & $\begin{array}{c}\text { Coordinates } \\
\text { (lat, long) }\end{array}$ & $\begin{array}{c}\text { Distance } \\
\text { Hitch (cm) }\end{array}$ & $\begin{array}{c}\text { Compass } \\
\left(^{\circ}\right)\end{array}$ & $\begin{array}{l}\text { Speed } \\
\text { (knots) }\end{array}$ & $\begin{array}{c}\text { Distance } \\
\text { Boats- } \\
\text { Objective } \\
\text { (m) }\end{array}$ \\
\hline 1. & \multirow{7}{*}{$\begin{array}{c}\text { Serial } \\
\text { Monitor }\end{array}$} & $\begin{array}{l}0.912374 \\
104.45508\end{array}$ & 330 & 134 & $0: 02$ & $10: 15$ \\
\hline 2. & & $\begin{array}{l}0.912364 \\
104.45510\end{array}$ & 329 & 133 & $0: 05$ & $8: 12$ \\
\hline 3. & & $\begin{array}{l}0.912357 \\
104.45512\end{array}$ & 325 & 134 & $0: 03$ & $6: 51$ \\
\hline 4. & & & & & & \\
\hline 5. & & $\begin{array}{c}0.91247 \\
104.45513\end{array}$ & 321 & 137 & $0: 05$ & 4:48 \\
\hline 6. & & $\begin{array}{l}0.912332 \\
104.45514\end{array}$ & 275 & 136 & 0:04 & 2.65 \\
\hline 7. & & $\begin{array}{l}0.912317 \\
104.45520\end{array}$ & 52 & 135 & $0: 01$ & $0: 46$ \\
\hline 8. & \multirow{7}{*}{ Database } & $\begin{array}{l}\frac{10.7 .4520}{0.912374} \\
104.45508\end{array}$ & 330 & 134 & $0: 02$ & $10: 15$ \\
\hline 9. & & $\begin{array}{l}0.912364 \\
104.45510\end{array}$ & 329 & 133 & $0: 05$ & $8: 12$ \\
\hline 10. & & $\begin{array}{l}0.912357 \\
104.45512\end{array}$ & 325 & 134 & $0: 03$ & $6: 51$ \\
\hline 11. & & & - & - & - & - \\
\hline 12. & & $\begin{array}{c}0.91247 \\
104.45513\end{array}$ & 321 & 137 & $0: 05$ & $4: 48$ \\
\hline 13. & & $\begin{array}{l}0.912332 \\
10445514\end{array}$ & 275 & 136 & $0: 04$ & 2.65 \\
\hline 14. & & $\begin{array}{c}0.912317 \\
104.45520\end{array}$ & 52 & 135 & 0:01 & $0: 46$ \\
\hline
\end{tabular}

Table 2. Testing Using Axis Card

\begin{tabular}{|c|c|c|c|c|c|c|}
\hline \multirow[b]{2}{*}{ No. } & \multirow[b]{2}{*}{$\begin{array}{l}\text { How to } \\
\text { Capture }\end{array}$} & \multicolumn{5}{|c|}{ Data } \\
\hline & & $\begin{array}{l}\text { Coordinates } \\
\text { (lat, long) }\end{array}$ & $\begin{array}{c}\text { Distance } \\
\text { Hitch (cm) }\end{array}$ & $\begin{array}{c}\text { Compass } \\
\left({ }^{\circ}\right)\end{array}$ & $\begin{array}{l}\text { Speed } \\
\text { (knots) }\end{array}$ & $\begin{array}{c}\text { Distance } \\
\text { Boats- } \\
\text { Objective (m) }\end{array}$ \\
\hline 1. & \multirow{6}{*}{ Serial Monitor } & $\begin{array}{c}0.912374 \\
104.45508 \\
\end{array}$ & 332 & 135 & $0: 01$ & $10: 25$ \\
\hline 2. & & $\begin{array}{c}0.912365 \\
104.45510\end{array}$ & 323 & 133 & $0: 05$ & $8: 12$ \\
\hline 3. & & $\begin{array}{c}0.912357 \\
104.45512\end{array}$ & 325 & 134 & $0: 03$ & $6: 31$ \\
\hline 5. & & $\begin{array}{c}0.91247 \\
104.45513 \\
\end{array}$ & 313 & 137 & 0:05 & $4: 48$ \\
\hline 6. & & $\begin{array}{c}0.912333 \\
104.45514 \\
\end{array}$ & 221 & 135 & $0: 04$ & 2.65 \\
\hline 7. & & $\begin{array}{c}0.912317 \\
104.45520\end{array}$ & 22 & 136 & $0: 02$ & 032 \\
\hline 8. & \multirow{6}{*}{ Database } & $\begin{array}{c}0.912374 \\
104.45508\end{array}$ & 332 & 135 & $0: 01$ & $10: 25$ \\
\hline 9. & & $\begin{array}{r}0.912365 \\
104.45510 \\
\end{array}$ & 323 & 133 & $0: 05$ & $8: 12$ \\
\hline 10. & & $\begin{array}{r}0.912357 \\
104.45512 \\
\end{array}$ & 325 & 134 & $0: 03$ & $6: 31$ \\
\hline 12. & & $\begin{array}{c}0.91247 \\
104.45513 \\
\end{array}$ & 313 & 137 & $0: 05$ & 4:48 \\
\hline 13. & & $\begin{array}{c}0.912333 \\
104.45514 \\
\end{array}$ & 221 & 135 & $0: 04$ & 2.65 \\
\hline 14. & & $\begin{array}{c}0.912317 \\
104.45520 \\
\end{array}$ & 22 & 136 & $0: 02$ & 032 \\
\hline
\end{tabular}

Table 3. Testing Using IM3 Card

\begin{tabular}{|c|c|c|c|c|c|c|}
\hline \multirow[b]{2}{*}{ No. } & \multirow[b]{2}{*}{$\begin{array}{l}\text { How to } \\
\text { Capture }\end{array}$} & \multicolumn{5}{|c|}{ Data } \\
\hline & & $\begin{array}{c}\text { Coordinates } \\
\text { (lat, long) }\end{array}$ & $\begin{array}{c}\text { Distance } \\
\text { Hitch (cm) }\end{array}$ & $\begin{array}{c}\text { Compass } \\
\left({ }^{\circ}\right)\end{array}$ & $\begin{array}{l}\begin{array}{l}\text { Speed } \\
\text { (knots) }\end{array} \\
\text { ( }\end{array}$ & $\begin{array}{c}\text { Distance } \\
\text { Boats- } \\
\text { Objective (m) }\end{array}$ \\
\hline 1. & \multirow{8}{*}{$\begin{array}{c}\text { Serial } \\
\text { Monitor }\end{array}$} & $\begin{array}{c}0.912375 \\
104.45508 \\
\end{array}$ & 327 & 136 & $0: 02$ & $10: 05$ \\
\hline 2. & & - & - & - & - & - \\
\hline 3. & & $\begin{array}{c}0.912363 \\
104.45510\end{array}$ & 329 & 135 & $0: 03$ & $8: 32$ \\
\hline 4. & & $\begin{array}{c}0.912357 \\
104.45512\end{array}$ & 316 & 133 & $0: 05$ & $6: 41$ \\
\hline 5. & & $\begin{array}{c}0.91247 \\
104.45513\end{array}$ & 323 & 137 & 0:04 & 4:28 \\
\hline 6. & & - & - & - & - & - \\
\hline 7. & & $\begin{array}{c}0.912332 \\
104.45514\end{array}$ & 241 & 136 & $0: 03$ & $2: 53$ \\
\hline 8. & & $\begin{array}{c}0.912318 \\
104.45521\end{array}$ & 55 & 137 & $0: 02$ & $0: 46$ \\
\hline 9. & \multirow{8}{*}{ Database } & $\begin{array}{c}0.912375 \\
104.45508\end{array}$ & 327 & 136 & $0: 02$ & 10:05 \\
\hline 10. & & - & - & - & - & - \\
\hline 11. & & $\begin{array}{c}0.912363 \\
104.45510 \\
\end{array}$ & 329 & 135 & $0: 03$ & $8: 32$ \\
\hline 12. & & $\begin{array}{c}0.912357 \\
104.45512 \\
\end{array}$ & 316 & 133 & $0: 05$ & $6: 41$ \\
\hline 13. & & $\begin{array}{c}0.91247 \\
104.45513\end{array}$ & 323 & 137 & $0: 04$ & $4: 28$ \\
\hline 14. & & - & - & - & - & - \\
\hline 15. & & $\begin{array}{c}0.912332 \\
104.45514\end{array}$ & 241 & 136 & $0: 03$ & $2: 53$ \\
\hline 16. & & $\begin{array}{c}0.912318 \\
104.45521\end{array}$ & 55 & 137 & $0: 02$ & $0: 46$ \\
\hline
\end{tabular}

Table 4. Testing Using Tri-Card

This monitoring system device is controlled by a microcontroller circuit using the GSM Shield SIM900 to work well, where the system can send data to the server using a SIM card (Subscriber Identity Module). GPS sensor readings such as point coordinates, speed, and distance of the ship have slightly different data when compared with the actual, and difference at least two numbers, as $0.912375 ; 104.45508$ and $0.912374 ; 104.45508$. From the sample data, there are only differences in latitude readings. If the data entry into Maps, the position is approximately only $20-40 \mathrm{~cm}$ different. Then in the reading of the ship's mileage, there is an error of 0.5 meters due to the inaccurate reading of the coordinates of the ship's position and destination. The results of the data from the compass sensor to get the direction of the vessel has different angles. That's because the sensitivity level of the compass module is not quite right.

The test data using four different providers shows that the sympathy card has stable signal connectivity and can send comprehensive data to the database compared to other cards (Table 5). This is also corroborated by several previous studies, which state that Telkomsel 
providers are more stable than other providers [15-17]. The signal strength or also called milliwatt decibels $(\mathrm{dBm})$, is a powerful unit signal indicating the reception of signals from the Base Transceiver Station (BTS) nearby operator. To check the signal strength using the first mobile phone with a SIM card inserted alternately. Visually measure signal strength represented by a bar chart usually located in the right corner of the phone.

\begin{tabular}{|c|c|c|}
\hline No. & Card & Signal strength \\
\hline 1. & Simpati & $-65 \mathrm{dBm}$ \\
\hline 2. & Axis & $-77 \mathrm{dBm}$ \\
\hline 3. & iM3 & $-97 \mathrm{dBm}$ \\
\hline 4. & Tri & $-81 \mathrm{dBm}$ \\
\hline
\end{tabular}

Table 5. Signal Strength Each Card

Strong signals on internationally mobile phones, also known as Received Signal Strength Indicator (RSSI) with $-110 \mathrm{dBm}$ is no signal, and a value close to $0 \mathrm{dBm}$ is a 'strong signal. The RSSI is a parameter that indicates the power received from around the measured signal. Table 6 shows the signal strength based on the RSSI value [18].

\begin{tabular}{|l|l|}
\hline \multicolumn{1}{|c|}{ RSSI } & SIGNAL STRENGTH \\
\hline$>-70 \mathrm{dBm}$ & Very good \\
\hline$-70 \mathrm{dBm}$ to $-85 \mathrm{dBm}$ & Well \\
\hline$-86 \mathrm{dBm}$ to $100 \mathrm{dBm}$ & Enough \\
\hline$<-100 \mathrm{dBm}$ & Bad \\
\hline$-110 \mathrm{dBm}$ & Fair Poor \\
\hline
\end{tabular}

Table 6. Classification Signal Strength

\section{Conclusion}

Based on the overall results of the system's design and testing, the monitoring system can display ship latitude-longitude position data in tabular form, can determine the distance obstacle in front of the ship, and the vessel's direction of motion can see on the monitor. In addition, the monitoring system can also determine the ship's speed based on changes in the coordinates of the latitude-longitude ship. Finally, it can determine the distance to the destination of a boat. Then the best signal strength is using a sympathy card provider with a signal strength of $-65 \mathrm{dBm}$.

\section{Acknowledgment}

The author would like to thank Allah for His mercy and guidance in completing this study. Also, thanks were given to the college of Raja Ali Haji Maritime University for financial support.

\section{References}

1. J. Juliana, Y. Wibawanti, and M. Haikal, Simetris: Jurnal Teknik Mesin, Elektro Dan Ilmu Komputer 9, 29 (2018).

2. M. E. Apriyani, R. Giovanny, and P. Y. Haris, Jurnal Integrasi 4, 200 (2012).
3. C. D. Whitaker, Vehicle Movement Monitoring System (United States, 1987).

4. M. Dwiyantiti, D. Ashari, and K. M. Nitisasmita, Jurnal Ilmiah Elite Elektro 2, 122 (2011).

5. S. M. Chaware, S. Dighe, A. Joshi, N. Bajare, and R. Korke, International Journal of Innovative Research in Electrical, Electronics, Instrumentation and Control Engineering 3297, 2321 (2007).

6. P. W. Digarse and S. L. Patil, in 2017 International Conference on Intelligent Computing and Control Systems (ICICCS) (IEEE, 2017), pp. 583-588.

7. S. N. Mahmood, A. J. Ishak, and S. T. Hussain, Periodicals of Engineering and Natural Sciences (PEN) 7, 670 (2019).

8. E. Prayetno, D. Nusyirwan, R. R. Putra, R. Saputra, and B. Anggara, Journal of Innovation and Technology 1, 79 (2020).

9. R. Ionel, G. Vasiu, and S. Mischie, Measurement 45, 1462 (2012).

10. Y. S. Susilo and H. Pranjoto, Widya Teknik 13, 21 (2017).

11. H. Zhang, Y. Liang, Q. Zhou, H. Fan, and J. Dai, in 2012 IEEE 2nd International Conference on Cloud Computing and Intelligence Systems (IEEE, 2012), pp. 1137-1140.

12. P. Gour and R. Nikose, International Journal Of Core Engineering \& Management (IJCEM) 1, 76 (2014).

13. I. Journal, S. Chakole, P. Khadse, S. Shinganjude, P. Pimple, S. Shahane, and S. Mokhale, International Research Journal of Engineering and Technology 4, 1126 (2017).

14. M. Jalilian, H. Sariri, F. Parandin, M. M. Karkhanehchi, M. Hookari, M. A. Jirdehi, and R. Hemmati, International Journal of Electrical Power \& Energy Systems 74, 36 (2016).

15. F. Oktafani and B. Suryawardani, Journal of Physics: Conference Series 1375, 012091 (2019).

16. S. N. A. Darmantya, (2020).

17. A. Alamsyah, E. Sofyan, B. E. Aprilliyanti, and V. N. Aini, Advanced Science Letters 23, 3813 (2017).

18. D. A. Simarmata and M. Samosir, BEES: Bulletin of Electrical and Electronics Engineering 1, 26 (2020). 